\title{
EFFECTS OF GARCINIA CAMBOGIA PLANT EXTRACTS ON SOME BIOCHEMICAL PARAMETERS OF EXPERIMENTAL RATS BLOOD
}

\author{
SAMIA ALI AL-ASKALANY \\ Special Food and Nutrition Dept., Food Technology Res. Inst. ARC, Giza, Egypt
}

(Manuscript received 17 July 2017)

\begin{abstract}
G arcinia plant is extensively used in herbal medicine and as food in the tropical rain forest region. The present study determined chemical composition of dried Garcinia cambogia fruits, hydroxyl citric acid. The antioxidant activity of their hot and cold (10\%) Garcinia cambogia extracts was determined by using 1, 1-diphenyl-2-picrylhydrazyl (DPPH). The study also, investigated the effects of Garcinia cambogia extract $(10 \%)$ hot and cold on some blood parameters of experimental rats to show their effects on health. The biological experiments consisted of 18 male rats, divided into 3 groups (control, hot and cold $10 \%$ Garcinia cambogia extracts). The effects of extracts on liver and kidney functions as well as lipid profile of blood were estimated. Garcinia cambogia $(10 \%)$ extracts $(2 \mathrm{ml} \mathrm{w} / \mathrm{v})$ were given twice daily by using stomach tube. Chemical composition of dried Garcinia cambogia showed that fruits contained $19.8 \%$ of fat and $66 \%$ carbohydrates while possessed $0.22 \%$ protein. Meanwhile it contained some minerals such as calcium $(180 \mathrm{mg} / 100 \mathrm{~g})$ iron $(150$ $\mathrm{mg} / 100 \mathrm{~g})$, magnesium $(80 \mathrm{mg} / 100 \mathrm{~g})$ as well as few amounts of zinc $(2 \mathrm{mg} / 100 \mathrm{~g})$ and copper $(2 \mathrm{mg} / 100 \mathrm{~g})$. Hydroxycitric acid (HCA) amount was $8 \%$, while showed high antioxidant activity in cold extract than that found in hot. The effect of Garcinia cambogia extracts on blood parameters of rats showed a significant decreament (at $P<0.05$ ) in total lipid, triglycerides, cholesterol, LDL-C, vLDL-C, glucose, albumin, creatinine, urea, ALT and AST activity, while HDL increased compared with control. Total protein and uric acid, showed no significant difference in all groups. It could be concluded that Garcinia cambogia plants has a high antioxidant property and has positive effects on different items of investigated biochemical blood tests. The optained natural extracts possess some benefits effect on health and can be used as a natural preservative substance in food and beverages.
\end{abstract}

Key words: biochemical analysis, antioxidant, Garcinia cambogia and hydroxycitric acid.

\section{INTRODUCTION}

Garcinia plant is extensively used in herbal medicine and as food, usually found in tropical rain forest region. It prevails as multipurpose tree crops in the home gardens of southern Nigeria. With the shifting of attention from synthetic drugs to natural plant products, the use of plant extracts for disease treatment is now on the increase. Plants that were once developed into drugs had little or no side effects. 
(Nzegbule and Mbakwe, 2001). Some studies have indicated that phenolic substances such as flavonoids and phenolic acids are considerably more potent antioxidants than vitamins $\mathrm{C}$ and $\mathrm{E}$. The bioactive components can effectively inhibit LDL oxidation and may prevent atherosclerosis by reducing and slowing down the progression to the advance stage (Hodzic et al., 2009). Recently, hydroxyl citric acid has been found to be used as a potent metabolic regulator of obesity and lipid abnormalities in mammalian system. Garcinia is loaded with B-complex vitamins, and minerals like potassium, manganese and magnesium, that help in controlling heart rate and blood pressure, offering protection against stroke and coronary heart diseases. This Garcinia fruit has been used to counter digestive problems such as indigestion, flatulence, acidity and constipation. The fruit possess useful antioxidant, chelating, anti-cancer, anti-fungal, anti-inflammatory, antibacterial, cardio protective and anti-ulcer activities (Manikanta, 2004). Garcinia atroviridis or commonly named as 'Asam Gelugur' among locals is extensively used as flavoring agent to provide sour sensation. Apart from being used as flavoring agent, $G$. atroviridis is also used in many ways to traditionally promote health (Hamidon et al., 2017).

The present study aimed to evaluate the chemical composition of dried Garcinia cambogia, determined the amounts of hydroxycitric acid and antioxidant activity. The study will estimate the effects of $10 \%$ hot and cold Garcinia extracts on lipid profile, liver and kidney functions of experimental rats to can be used safely as a natural healthy substance in food.

\section{MATERIALS AND METHODS}

\section{Materials:}

Garcinia combogia dried fruits were purchased from the folk medicine market in Cairo. Starch and sun flower oil were purchased from local market in Cairo. Casein, salt and vitamin mixtures were obtained from El- Gomhoria Campany, Cairo, Egypt. Hydroxycitric acid (HCA) standard was purchased from Sigma Chemical Company.

\section{Methods of Garcinia Cambogia extract preparation:}

The whole dried Garcinia cambogia fruits were cleaned and milled by Moulinex caba (type 843, code 243, 220 vac $50 \mathrm{~Hz} 750 \mathrm{~W}$ ) at 3000 RCF for 4 minutes at room temperature to obtain a homogenate powder.

\section{Cold extract:}

Exactly $20 \mathrm{gm}$ of Garcinia cambogia powder were added to $200 \mathrm{ml}$ of distilled water in conical flask to prepare $10 \%$ concentration (w/v) cold extract, and left for 24 hours. The extract was filtered and kept in washed and sterilised glass bottle at refrigerator at $\left(5 \pm 1 \mathrm{C}^{\circ}\right)$ until used. 


\section{Hot extract:}

Exactly $20 \mathrm{gm}$ of Garcinia cambogia powder in conical flask were added to $200 \mathrm{ml}$ of boiled water to prepare $10 \%$ ratio $(\mathrm{w} / \mathrm{v})$ hot extract. The flask contains extract was covered and left to cool. The prepared extract was filtered and kept in washed and sterilised glass bottles and kept at a refrigerator at $\left(5 \pm 1 C^{\circ}\right)$ until used (Abd El Hafez, 2012).

\section{Analytical methods:}

Protein, ash, fat, fibre and mineral contents were determined according to the method of AOAC, (2005) while total carbohydrates were estimated by difference. Hydroxy citric acid (HCA) in Garcinia combogia was determined by using HPLC apparatus according to Wodecki, et al., (1991) method. HCA was extracted by using phosphoric acid $(0.1 \% \mathrm{v} / \mathrm{v})$ from Garcinia dried fruits. The clear filtrate was injected into Helwellet Packared 1050 HPLC fitted with C18 column (250X $4.6 \mathrm{~mm}$ ). Ultraviolet (UV) detector set and quarter HP (series 1050). The column temperature was $55 \mathrm{C}^{\circ}$ throughout the analysis. Retention time of standard HCA was used to characterize HCA of Garcinia. A calibration curve of HCA was used to quantify the level of HCA in the fruit sample by the data analysis of HPLC apparatus. Antioxidant activity of sample extracts was studied through the evaluation of the free radical-scavenging effect on the 1, 1-diphenyl-2-picrylhydrazyl (DPPH) radical. The results were expressed as percentage of inhibition of the DPPH radical. Percentage of inhibition of the DPPH radical was calculated according to Alothman et al., (2009).

\section{Biological Study:}

The experiment was performed in the animal house of Research Institute of Ophthalmology, Giza, Egypt. The experiment was operated by using 18 normal Sprague Dawley male rats (weighted $160-170 \mathrm{gm}$ ) to study the safety effects of Garcinia cambogia extracts (10\% cold and hot extracts) on some blood parameters such as lipid profile, liver function and kidney functions. The rats were adapted by feeding on basal diet for one week before the initiation of the experiment Zamora et al., (1991). The experimental rats were divided into 3 groups; each group contained 6 rats. Group 1 (control) was fed on basal diet for along all the experiment period ( 6 weeks). While the other two groups (group 2 and 3) fed on basal diet and $2 \mathrm{ml} \mathrm{w} / \mathrm{v}$ of Garcinia cambogia (10\% cold and hot extracts) were taken twice daily by using stomach tube.

\section{Blood Samples Preparation:}

At the end of experiment, blood samples were withdrawn and biochemical blood analysis of rats were studied. The blood samples of the experiment rats were 
taken from orbital plexus venous by using fine capillary glass tubes. Blood samples were allowed to clot for $10 \mathrm{~min}$ at $37^{\circ} \mathrm{C}$ and centrifuged at $3000 \mathrm{RCF}$ for 10 minutes, and then the separated serum was frozen and kept at $-18^{\circ} \mathrm{C}$ until assayed.

\section{Biological Assays}

Aspartate aminotransferase (AST) and Alanine aminotransferase (ALT) activities were colorimetric estimated according to Reitman and Frankel (1957). Total cholesterol, triglycerides and glucose were determined by the colorimetric method according to Trinder (1969). HDL was determined according to Assman (1979). Total lipid, LDL and vLDL were determined according to Fruchart (1982). Total protein and albumin concentrations were determined by the method of Doumas et al., (1971). Creatinine, urea and uric acid were determined according to Thomas, (1998) methods.

\section{Statistical analysis:}

Collected data were subjected to the analysis of variance by using Duncan multiple range test procedure at $\mathrm{P}<0.05$ as described in the SAS soft ware (SAS, 2002).

\section{RESULTS AND DISCUSSION}

\section{Chemical composition of Garcinia cambogia:}

Chemical composition of dried Garcinia cambogia fruits is presented in Table (1). The data showed that Garcinia cambogia contained $19.8 \%$ crude fat (ether extract), $0.22 \%$ protein, $3.1 \%$ ash $10.88 \%$ crude fibre and $66 \%$ carbohydrates, on dry basis. Meanwhile Table (2) showed that it was contained a reasonable amount of minerals such as calcium $(180 \mathrm{mg} / 100 \mathrm{~g})$ and iron $(150 \mathrm{mg} / 100 \mathrm{~g})$ as well as few amounts of zinc $(2.0 \mathrm{mg} / 100 \mathrm{~g})$, copper $(2.0 \mathrm{mg} / 100 \mathrm{~g})$ and magnesium $(80 \mathrm{mg} / 100 \mathrm{~g})$. These data are in accordance with those found by Abd El Hafez, (2012) who mentioned that Garcinia cambogia is characterized by low protein contents, high carbohydrates and moderate amounts of crude fibres and ash also, it contains considerable amounts of minerals.

Table 1. Chemical composition of Garcinia cambogia dried fruits $(\mathrm{g} / 100 \mathrm{~g})$ on dry basis:

\begin{tabular}{|c|c|c|c|c|c|}
\hline Raw material & $\begin{array}{c}\text { Crud Fat } \\
\%\end{array}$ & $\begin{array}{c}\text { Protein } \\
\%\end{array}$ & $\begin{array}{c}\text { Crude fibre } \\
\%\end{array}$ & $\begin{array}{c}\text { Ash } \\
\%\end{array}$ & Total Carbohydrates \% \\
\hline Garcinia & 19.8 & 0.22 & 10.88 & 3.1 & 66 \\
\hline
\end{tabular}

${ }^{*}$ Total carbohydrate was estimated by difference.

Table 2. Mineral contents in raw Garcinia cambogia (mg/100g) on dry basis:

\begin{tabular}{|c|c|c|c|c|c|}
\hline $\begin{array}{c}\text { Raw } \\
\text { material }\end{array}$ & $\begin{array}{c}\text { Calcium } \\
(\mathrm{Ca})\end{array}$ & $\begin{array}{c}\text { Iron } \\
(\mathrm{Fe})\end{array}$ & $\begin{array}{c}\text { Zinc } \\
(\mathrm{Zn})\end{array}$ & $\begin{array}{c}\text { Copper } \\
(\mathrm{Cu})\end{array}$ & $\begin{array}{c}\text { Magnesium } \\
(\mathrm{Mg})\end{array}$ \\
\hline Garcinia & 180 & 150 & 2.0 & 2.0 & 80 \\
\hline
\end{tabular}


The data in Table (3) showed that the hydroxycitric acid (HCA) contents and DPPH activity of cold and hot Garcinia cambogia extracts. The hydroxycitric acid (HCA) was recorded $8 \%$. Manikanta, (2004) mentioned that hydroxycitric acid (HCA) is a principle constituent (10-30\%) of the dried fruit rind of Garcinia cambogia. HCA has undergone considerable formal safety, without the evidence of toxicity appearing.

The decreasing of HCA under study may be return to storage of plants at folk medicine.

The same table data showed high antioxidant activity of $10 \%$ Garcinia cambogia cold extract ( $69.8 \%$ of inhibition of DPPH radical) than that found in the $10 \%$ hot extract (36.36 \% of inhibition of DPPH radical). The polyphenol contents of extracts were quantified by Folin-Ciocalteau's reagent assay and expressed as gallic acid equivalents ( $\mu \mathrm{g} \mathrm{GAE} / \mathrm{g}$ ). Ritthiwigrom et al., (2013) mentioned that higher antioxidant activity (DPPH) of some fruits exhibited perhaps are due to the linear correlation between antioxidant activity and total soluble phenols which could be useful to consumers to plan antioxidant rich diets and their impact in health and disease.

Table 3. Hydroxycitric acid (HCA) contents and (DPPH) activity in Garcinia cambogia on dry basis:

\begin{tabular}{|c|c|c|c|}
\hline $\begin{array}{c}\text { Raw } \\
\text { material }\end{array}$ & hydroxycitric acid (HCA $)^{*}$ & $\begin{array}{c}\text { DPPH activity \% } \\
\text { of cold Garcinia extract }\end{array}$ & $\begin{array}{c}\text { DPPH activty \% } \\
\text { of hot Garcinia extract }\end{array}$ \\
\hline Garcinia cambogia & 8 & 69.8 & 36.36 \\
\hline
\end{tabular}

*HCA: $\mathrm{g} / 100 \mathrm{~g}$

Total lipids, triglycerides, total cholesterol, HDL-C, LDL-c and vLDL-c $(\mathrm{mg} / \mathrm{dl})$ in serum rats fed on (10\%cold and hot) Garcinia cambogia extracts:

The effect of Garcinia cambogia (10\% cold and hot) extracts on total lipids, triglycerides, total cholesterol, HDL-C, LDL-C and VLDL-c in serum rats were recorded in Table (4). The data showed that a slightly significantly decreasing was detected in total lipid, triglycerides and VLDL-C at $(P<0.05)$ compared with control. Total cholesterol and LDL-C, showed a significantly difference decreasing in groups fed on Garcinia cambogia extracts ( $10 \%$ cold and hot). While HDL-c showed a significantly difference increasing in groups fed on $10 \%$ cold and hot Garcinia cambogia extracts comparing with control. Al-Mansoub et al., (2013) mentioned that Garcinia fruit juice affected on body weight and cholesterol reduction ability in rats. The treatment was successfully reduced the LDL-c cholesterol level. Darji et al., (2010) illustrated that the methanolic extract of the dried fruit of Garcinia type kokum showed remarkable antihyperlipidemic activity in rats, using cholesterol induced hyperlipidemic model 
diets. A significant decrease in total cholesterol, triglycerides, LDL-c, VLDL-c levels and increase in HDL-c was reported.

Table 4. Total lipids, triglycerides, total cholesterol, HDL-C, LDL-C and vLDL -c in serum rats fed on $10 \%$ (cold and hot) Garcinia Cambogia extracts:

\begin{tabular}{|l|c|c|c|c|c|c|}
\hline \multicolumn{1}{|c|}{$\begin{array}{c}\text { Rat } \\
\text { Groups }\end{array}$} & Total lipid $^{*}$ & Triglycerides $^{*}$ & Total cholestero $^{*}$ & HDL-c & LDL-c & v LDL-c $^{*}$ \\
\hline Control & $270 \pm 1.15^{\mathrm{a}}$ & $129.52 \pm 0.19^{\mathrm{a}}$ & $120.27 \pm 0.07^{\mathrm{a}}$ & $49.99 \pm 0.01^{\mathrm{c}}$ & $44.81 \pm 0.22^{\mathrm{a}}$ & $25.90 \pm 0.01^{\mathrm{a}}$ \\
$10 \%$ cold extract & $266 \pm 1.15^{\mathrm{b}}$ & $127.62 \pm 0.13^{\mathrm{b}}$ & $119.22 \pm 0.13^{\mathrm{b}}$ & $52.80 \pm 0.06^{\mathrm{b}}$ & $40.92 \pm 0.17^{\mathrm{b}}$ & $25.50 \pm 0.09^{\mathrm{b}}$ \\
$10 \%$ hot extract & $268 \pm 0.58^{\mathrm{ab}}$ & $129.45 \pm 0.25^{\mathrm{a}}$ & $119.50 \pm 0.0 .06^{\mathrm{b}}$ & $53.50 \pm 0.25^{\mathrm{a}}$ & $40.40 \pm 0.16^{\mathrm{ab}}$ & $25.80 \pm 0.11^{\mathrm{b}}$ \\
\hline
\end{tabular}

Each mean value, within the same column, followed by the same letter is not significantly different at 0.05 level. Each value, mean of three replicates, is followed by \pm standard deviation. $* m g / d l$

\section{Albumin, total protein, glucose, ALT and AST activity in serum rats fed on 10\% (cold and hot) Garcinia cambogia extracts:}

Total protein $(\mathrm{g} / \mathrm{dl})$, albumin $(\mathrm{g} / \mathrm{dl})$, glucose $(\mathrm{mg} / \mathrm{dl})$, ALT (U/L) and AST (U/L) activity in serum rats fed on cold and hot Garcinia cambogia extracts was recorded in Table (5). Total protein showed that no a significant difference among groups fed on Garcinia cambogia extracts ( $10 \%$ cold and hot) and control. The results recorded a slight significant difference decreased in albumin $(P \leq 0.05)$ of rats fed on $10 \%$ Garcinia cambogia cold extracts comparing with hot extract and control. Glucose and ALT activity were showed that a significant difference decreasing among groups fed on Garcinia cambogia extracts ( $10 \%$ cold and hot) and control meanwhile, there was no significant difference either hot or cold groups. AST activity also, was showed a significantly difference decreased in groups fed on Garcinia cambogia extracts (10\% cold and hot) relative control.

From data it was found that Garcinia cambogia extracts improved liver enzymes (AST and ALT activity) and glucose while was no effects in total protein. Gogoi et al., (2012) who reported that aqueous and ethanolic extract of Garcinia indica Linn fruit has showed a hepatoprotective effect on liver which lower toxicity on wistar albino rats and the degree of liver protection increased. The presented data revealed that biochemical analysis of blood parameters showed decreasing in lipid profile, improving liver functions meanwhile increasing in $\mathrm{HDL}-\mathrm{c}$.

Table 5. Total protein, albumin, glucose, ALTand AST activity in serum rats fed on (10\% cold and hot) Garcinia cambogia extracts:

\begin{tabular}{|c|c|c|c|c|c|}
\hline $\begin{array}{c}\text { Rat } \\
\text { groups }\end{array}$ & Total protein* & Albumin* & Glucose ${ }^{* * *}$ & ALT $^{* *}$ & AST $^{* *}$ \\
\hline Control & $5.17 \pm 0.15^{\mathrm{a}}$ & $3.77 \pm 0.09^{\mathrm{a}}$ & $84.22 \pm 0.13^{\mathrm{a}}$ & $38.12 \pm 0.07^{\mathrm{a}}$ & $48.22 \pm 0.13^{\mathrm{a}}$ \\
$10 \%$ cold E. & $5.03 \pm 0.19^{\mathrm{a}}$ & $3.23 \pm 0.09^{\mathrm{b}}$ & $82.33 \pm 0.06^{\mathrm{b}}$ & $35.65 \pm 0.13^{\mathrm{b}}$ & $44.52 \pm 0.19^{\mathrm{c}}$ \\
$10 \%$ hot E. & $5.23 \pm 0.20^{\mathrm{a}}$ & $3.40 \pm 0.17^{\mathrm{ab}}$ & $82.31 \pm 0.07^{\mathrm{b}}$ & $35.99 \pm 0.06^{\mathrm{b}}$ & $45.11 \pm 0.06^{\mathrm{b}}$ \\
\hline
\end{tabular}

Each mean value, within the same column, followed by the same letter is not significantly different at 0.05 level. Each value, mean of three replicates, is followed by \pm standard deviation.

$* \mathrm{~g} / \mathrm{dl} \quad * * \mathrm{U} / \mathrm{L} \quad * * * \mathrm{mg} / \mathrm{dl}$ 
Urea, createnine and uric acid $(\mathrm{mg} / \mathrm{dl})$ in serum rats fed on cold and hot Garcinia cambogia extracts was recorded in Table (6). The results showed a slightly significant difference decreased in urea and creatinine of rats fed on $10 \%$ Garcinia cambogia extracts ( $10 \%$ cold and hot) relative control. Uric acid was showed no a significant difference in all groups comparing to control. The data revealed that Garcinia cambogi extracts $10 \%$ cold more effective on Urea and createnine than hot while was no effects on uric acid.

Table 6. Urea, creatnien and uric acid levels in serum rats fed on (10\% cold and hot) Garcinia cambogia extracts:

\begin{tabular}{|c|c|c|c|}
\hline Rat groups & Urea $*$ & Creatinine* & Uric acid* \\
\hline Control & $25.11 \pm 0.07^{\mathrm{a}}$ & $1.50 \pm 0.10^{\mathrm{a}}$ & $1.70 \pm 0.15^{\mathrm{a}}$ \\
$10 \%$ cold E. & $23.11 \pm 0.06^{\mathrm{c}}$ & $1.02 \pm 0.01^{\mathrm{b}}$ & $1.37 \pm 0.12^{\mathrm{a}}$ \\
$10 \%$ hot E. & $23.73 \pm 0.20^{\mathrm{b}}$ & $1.37 \pm 0.12^{\mathrm{a}}$ & $1.47 \pm 0.15^{\mathrm{a}}$ \\
\hline
\end{tabular}

Each mean value, within the same column, followed by the same letter is not significantly different at 0.05 level. Each value, mean of three replicates, is followed by \pm standard deviation. $* \mathrm{mg} / \mathrm{dl}$

\section{CONCLUSION}

From the above studies, it could be concluded that Garcinia cambogia natural plant extract was a good natural antioxidant which acts as a protective agent against free radical substances in the body. It has a protective agent on some health parameters. These potential beneficial effects enable to be used as an additive substance for food quality and health.

\section{REFERENCES}

1. Abd El Hafez, M. S. 2012. Effect of Garcinia cambogia Fruits on Feeding Behaviour and Body Weight of Rats. Ph.D. Thesis,. Faculty of Agri., Dept., of Food Sci., and Tech., Cairo Univ.

2. Alothman, M.; Bhat R. and Karim, A. A. 2009. Antioxidant capacity and phenolic content of selected tropical fruits from Malaysia, extracted with different solvents. Food Chemistry, 115, 785-788.

3. Al-Mansoub, M. A.; Asmawi, M. and Murugaiyah V. 2013. Effect of extraction solvents and plant parts used on the antihyperlipidemic and antioxidant effects of Garcinia atroviridis: a comparative study. J Sci. Food Agric; 94: 1552-8.

4. AOAC, 2005. Official Methods of the Association of Official Analytical Chemists $18^{\text {th }}$ Ed. Washington, D.C., USA.

5. Assman, G. 1979. A fully enzymatic colorimetric determination of HDL-cholesterol in serum. Internist., 20: 559-563.

6. Darji, K.K.; Shetgiri, P. and D'mello, P. M. 2010. Evaluation of antioxidant and Anti-hyperlipidemic activity of extract of Garcinia indica., Int. J. Pharm. Sci. Res., 1(12):175-81. 
7. Doumas, B. T.; Watson, W. A. and Biggs, H. C. 1971. Albumin standers and measurement of albumin with bromocresol green. Clin. Chem. Acta., 31:87-95.

8. Fruchart, J. C. 1982. Metabolism of lipoprotein at the cellular level relation to atherogensis. Clin. Chem., 27(5): 653-662.

9. Gogoi, B. J.; Tsering, J.; Tag, H. and Veer, V. 2012. Antioxidant Potential of Garcinia Species from Sonitpur District, Assam, North East India. Int. J. Pharm. Sci. Res.;3(9):3472-3475.

10. Hamidon H.; Deny, S.; Taher M. and Zakaria, Z. A. 2017. Garcinia atroviridis - A review on phytochemicals and pharmacological properties. Marmara Pharmaceutical Journal, 21: 38-47.

11. Hodzic, Z.; Pasalic, H.; Memisevic, A.; Srabovic, M.; Saletovic, M. and Poljakovic, M. 2009. The Influence of total phenols content on antioxidant capacity in the whole grain extract. Eur. J. Sc. Res., 3: 471-477.

12. Manikanta, P. 2004. Methods for Isolation of Bioactive Constituents from Garcinia indica Choisy and Its Medicinal Importance: A Review International Journal of Universal Pharmacy and Bio. Sciences, 3(1):206-215.

13. Nzegbule, E. and Mbakwe, R. 2001. Effect of pre-sowing and incubation treatment on germination of Garcinia Kola Heckel seed. Fruita, 56:437-442.

14. Reitman, S. and Frankel, S. 1957. A colorimetric method for the determination of serum glutamic oxaloacetic and glutamic pyrovic transaminase. Am. J. Clin. Path., $28: 56-60$.

15. Ritthiwigrom, T.; Laphookhieo, S. and Stephen, G. P. 2013. Chemical constituents and biological activities of Garcinia cowa Roxb. Maejo Int. J. Sci. Technol., 7(02): 212-231.

16. SAS, 2002. Statistical Analysis System Proprietary Software. Release 8.3. SAS Institute Inc., Carry, NC.

17. Thomas, L. 1998. Clinical laboratory diagnostics. Led. Frankfurt: TH-Books vegiagsgesellschaft; 644-647.

18. Trinder, P. 1969. Determination of total cholesterol and triglyceride by enzymatic colourimetric method. Ann. Clin. Biochem., 6: 24-27.

19. Wodecki, Z. J.; Torlop, Z. and Slebioda, M. 1991. Chromatographic Separation of Citric acid for monitoring the mould process. J. Chrom., 8: 302-305.

20. Zamora, R.; F. J. Hidalogo, and A. A. Tappel. 1991. Comparative antioxidant effectiveness of dietary beta-carotene, vitamin $E$, Selenium and Coenzyme qloin rat erythrocytes endoplasm, J. Nutr., 121: 50-56. 


\section{تأثير مستخلص نبات الجارسنيا كمبوجيا على بعض \\ المواد البيوكيميائية ومكونات الام لفئران التجارب مئب}

\section{سامية على العسقلانى}

قسم بحوث الأغذية الخاصة والتغذية - معهد بحوث تكنولوجيا الاغذية- مركز البحوث الزراعية جيزة مصر

يستخدم نبات الجارسينا فى طب الاعثاب و الطعام فى المناطق الاستوائية الممطره

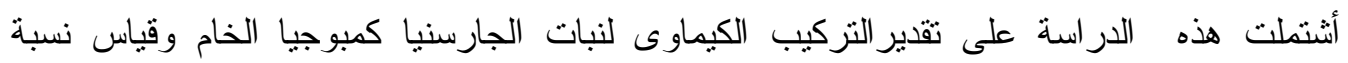
حامض الهيدروكسى سنرك و النشاط التأكسدى بأستخدام (DPPH) للمستخلص المائى الساخن و البارد

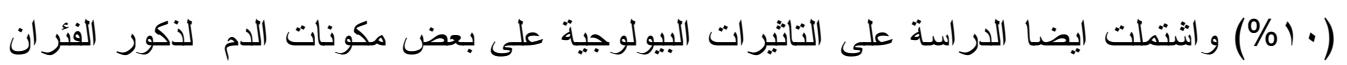
بأستخدام تركيز • ( ) للمستخلص المائى الساخن و البارد للنبات لدراسة التأثير الأمن للمستخلص على الصحة. وقد أجريت التجربة البيولوجية بأستخدام ثلاث مجموعات (الأولى) كنترول و(الثانية)

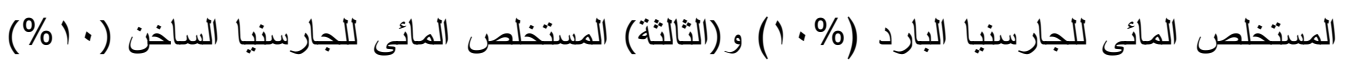

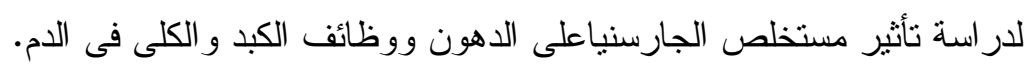
و أظهرت نتائج التحاليل الكيميائية لنبات الجارسنيا الجاف أنها تحتوى على الدهن و ( 77\%) من الكربو هيدرات و (r Y, · \% ) البروتين ومن جهة أخرى تحتوى على كمية من

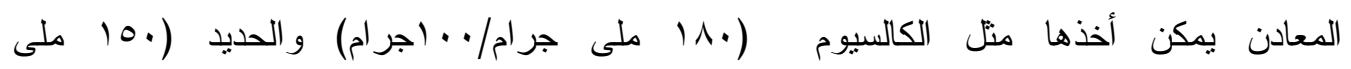

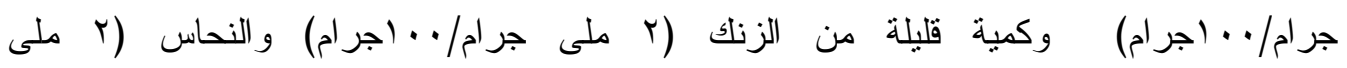

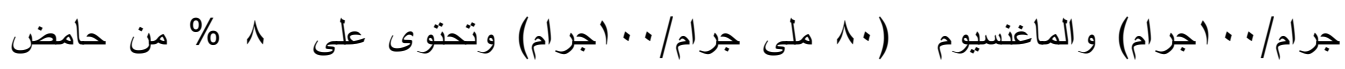

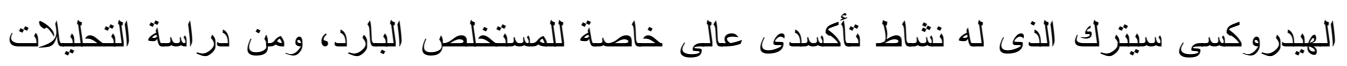
البيوكيميائية للام لفئران لوحظ وجود نقص فى دهون الدم والجلسريدات الثناثية والكولسترول

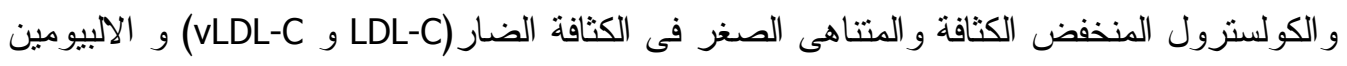

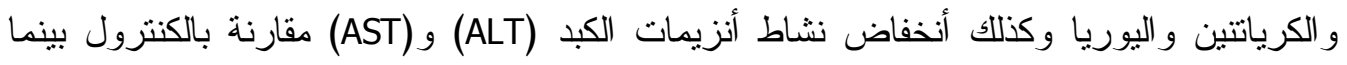

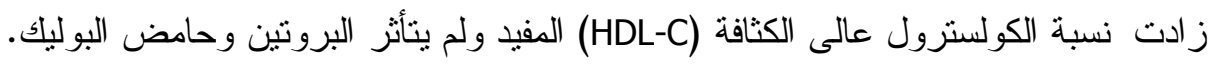

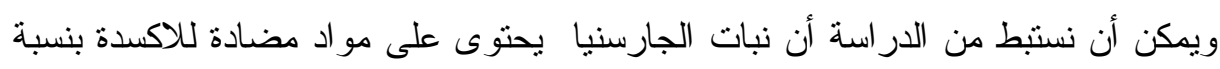
عالية و التى لها تأثير أيجابى على تحليلات الدم المختلفة وأن هذا المستخلص الطبيعى للجارسنيا له

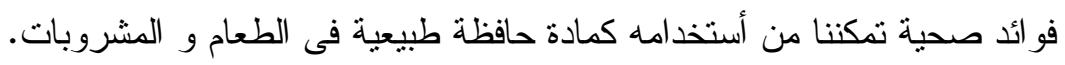

